\title{
Digital Transformation in Bank Perkreditan Rakyat in Encouraging Efficiency and Answering the Challenges of the New Era of Industry 4.0
}

\author{
Amne Gumilar Carlie Mudia ${ }^{1}$, Angelicha Aminah Zairuni Ussu ${ }^{2}$, Atika Mitzalina ${ }^{3}$ \\ \{amne.206032@mhs.its.ac.id ${ }^{1}$, angelicha.206032@mhs.its.ac.id², mitzalina.206032@mhs.its.ac.id ${ }^{3}$ \} \\ Institut Teknologi Sepuluh Nopember, Indonesia ${ }^{1,2,3}$
}

\begin{abstract}
Bank Perkreditan Rakyat (BPR) is a bank that carries out business activities conventionally and Financial Technology (Fintech) is a term with a sense related to the field of technology as well as the field economics (OJK, 2021). In 2020, the world was shocked by a deadly virus outbreak. This virus is a new type of virus called Coronavirus (SARS-CoV-2). The spread of the Covid-19 pandemic and Government policies also affect the banking industries, especially Bank Perkreditan Rakyat. Bank Perkreditan Rakyat has limitation in digital innovations, which is currently required to minimize direct contact. There are several factors influencing BPRs in digital innovations. This study aims to formulate the strategy through SWOT analysis on the conditions of Bank Perkreditan Rakyat in Indonesia. The research method used in this study was qualitative descriptive and SWOT analysis. The results of this study are 10 strategies with the main priorities of improving BPR services with digital including digitization of information access, digitization of services to customers, and digitization of BPR business processes and also, we make comparison with financial technology. The strategies obtained from this study are expected to be a suggestion for BPR and other related stakeholders.
\end{abstract}

Keywords: Bank Perkreditan Rakyat, Financial Technology, Electronic Banking

\section{Introduction}

In 2020, the world was shocked by a deadly virus outbreak. This virus is a new type of virus called Coronavirus (SARS-CoV-2). This virus can result in a disease called Coronavirus Disease 2019 (Covid-19). It is known that the origin of this virus is from Wuhan, China. Until this time, 223 countries have been exposed by Covid-19, one of which is Indonesia [1]. Coronavirus has several modes of transmission. Coronavirus transmission can be through droplets, air, contaminated surfaces, and fecal-oral or human waste. Based on the modes of transmission, some places are prone to the spread of Coronavirus. Places prone to the spread of Coronavirus are crowded places, narrow places, and confined and closed places.

Indonesia is recently in 20 th place with a total of $1,662,868$ confirmed cases with a mortality rate of 45,334 [2]. The government issued policies limiting the community activities as an attempt for handling Covid-19, including the Government Regulation of the Republic of Indonesia Number 21 of 2020 regarding the Large-Scale Social Restrictions for Accelerating the Handling of Coronavirus Disease 2019 (Covid-19) [3]. In the regulation is explained that Large-Scale Social Restrictions at least include closing the schools and workplaces, restrictions on religious activities, and/or the restrictions of activities in public places or facilities. These 
policies have many impacts on changes in community lifestyles, mainly the Mobility/Community Movements. Trends in data mobility/community movements are divided into Retail and Recreation occurring during pandemic until this time. Based on Our World In Data, the community movements in retail and recreation fields, such as the visitors of restaurant, cafe, shopping center, cinema, and others, have decreased up to -50\% (April 30, 2020), and until April 17, 2021, the community movements still have decreased up to $-20 \%$. In public transportation sectors, such as the passengers of the bus, train, plane, and others, have also decreased up to $-65 \%$ (April 30, 2020) and until this time still have decreased in $-30 \%$ (April 17, 2021). The park and open space sectors have decreased up to $-45 \%$ (April 20, 2020). However, until this time still has decreased by $-20 \%$. In the workplaces, mobility sector/community movements decreased up to $-50 \%$ on April 30, 2020, and until this time, April 17, 2021, has decreased by $-25 \%$. This occurred due to the impact of Work From Home and Work Termination [4].

The spread of the Covid-19 pandemic and Government policies also affect the banking industries, especially Bank Perkreditan Rakyat. Bank Perkreditan Rakyat, hereinafter abbreviated as BPR, is a bank implementing conventional business activities, where its activities do not provide services in payment traffic. The growth of BPR in 5 years can be seen in the following data.

Table 1. BPR growth in the last 5 years [5]

\begin{tabular}{lccccc}
\hline \multirow{2}{*}{ Data } & \multicolumn{5}{c}{ Years } \\
\cline { 2 - 6 } & $\mathbf{2 0 1 6}$ & $\mathbf{2 0 1 7}$ & $\mathbf{2 0 1 8}$ & $\mathbf{2 0 1 9}$ & $\mathbf{2 0 2 0}$ \\
\hline Total Credits & 81.684 & 89.482 & 98.220 & 108.784 & 110.540 \\
Total Assets & 1.633 & 1.619 & 1.597 & 1.546 & 1524 \\
Non-Performing Loan Ratio & 5,83 & 6,15 & 637 & 6,81 & 8 \\
Return of Assets & 2,59 & 2,55 & 2,48 & 2,31 & 2,11 \\
DPK & 75.725 & 84.861 & 91.956 & 102.538 & 106.151 \\
\hline
\end{tabular}

The business activities that can be implemented by BPR are fundraising in the form of time deposits, savings and loans received, distribution of funds, placement of funds, foreign exchange business activities, and other activities to support the business activities as an officeless financial service provider and agent for financial inclusions, and electronic banking services. In the Financial Services Authority Regulation Number 12/Pojk.03/2016 regarding the Business Activities and Office Network Areas of Bank Perkreditan Rakyat Based on Primary Capital, the business activities of BPR are in accordance with the BPRKU group enacted in Article 5 paragraph 2, where the provision of electronic banking is only available at BPRKU 3. Electronic banking includes phone banking, SMS banking, mobile banking, and internet banking. This means limiting other BPR innovations in developing digitalization in its services [6].

On the other hand, the growth of Fintech is increasing in Indonesia. There are 148 Fintech Companies registered in Otoritas Jasa Keuangan (OJK). The total assets of fintech organizers in Indonesia in 2020 reached IDR 3.71 trillion (increase in $22.23 \%$ YoY) [7]. From the data, it can be interpreted that in 2020 during the Covid-19 pandemic, the presence of Fintech is more facilitating people to borrow capital. The results of statistics stated that $67.19 \%$ who use fintech lending are people 19-34 years old. Currently, the total population of Indonesia is 260.20 million, with the compositions dominated by millennials of $25.87 \%$ and gen $\mathrm{z}$ of $27.94 \%$. Residents of that age are people who understand technology. 
This study aims to formulate the strategies through the external or internal weaknesses and financial factors with SWOT analysis in the Bank Perkreditan Rakyat (BPR) in Indonesia so that BPR can maintain its existence in the middle of the digital era.

\section{Methodology}

The methodology in the study was qualitative descriptive analysis and SWOT analysis. Qualitative descriptive analysis in the study is currently useful for exploring the conditions of digitalization in Bank Perkreditan Rakyat from internal or external factors. On the other hand, according to Rangkuti [8], SWOT analysis is an analysis based on the logic that can maximize the Strength and Opportunities but simultaneously can minimize the Weakness and Threats. Therefore, in this study, SWOT analysis was carried out to obtain recommendations in the digital transformation of Bank Perkreditan Rakyat (BPR).

\begin{tabular}{lll}
\hline & Strength (S) & Weakness (W) \\
\hline Opportunity (O) & $\begin{array}{l}\text { Strategies to take advantage of } \\
\text { opportunities to harness power } \\
\text { (S-O Strategy) }\end{array}$ & $\begin{array}{l}\text { Strategies to take advantage of } \\
\text { opportunities to overcome } \\
\text { weaknesses (W-O Strategy) }\end{array}$ \\
\hline Threats (T) & $\begin{array}{l}\text { Strategies to solve threats by } \\
\text { using force (S-T Strategy) }\end{array}$ & $\begin{array}{l}\text { Strategies to avoid threats while } \\
\text { protecting weaknesses (W-T } \\
\text { Strategy) }\end{array}$ \\
\hline
\end{tabular}

Fig. 1. Matrix SWOT (Lukmanul Almamalik, 2010).

The type of data used in this study was qualitative data obtained from secondary data sources. The steps in the study carried out were:

a. Identification of Strength, Weakness, Opportunities, and Threat of BPR Condition.

b. Formulate recommendations for the digital transformation of BPR with SWOT.

\section{Result}

\subsection{Fintech}

Fintech or Financial Technology is a term with a sense related to the field of technology as well as the field of economics. fintech aims to increase funding/finance by going through the online transaction process. It can be said that fintech is a merger between technology and the financial system [7].

Fintech regulation in Indonesia is directly supervised by the Otoritas Jasa Keuangan (OJK) and regulated by Bank Indonesia (BI). In Indonesia itself, several law foundations can be used related to fintech. There is a Circular Letter by Bank Indonesia with Number 18/22/DKSP concerning the Implementation of Digital Financial Services. Then there is also Bank Indonesia Regulation Number 18/40/PBI/2016 concerning The Implementation of Payment Transaction Processing. And Bank Indonesia Regulation Number 18/17/PBI/2016 on Electronic Money.

The existence of a valid legal basis regarding fintech in Indonesia provides convenience for fintech providers and users. Where the Otoritas Jasa Keuangan and Bank Indonesia have ensured the security and confidentiality of the data belonging to providers and users. According 
to the Otoritas Jasa Keuangan, fintech is also in line with the concept of the MasterPlan of the Indonesian Financial Services Sector (MPJKI), thus fintech can synergize with the financial industry to be able to provide multi-benefits to the community [9].

Fintech in Indonesia has so far registered as many as 149 companies. In the last three years from 2018 to 2020, the accumulation of national loans has always increased. Until now, the accumulation of national loans amounted to Rp. 155.90 trillion with an increase of 91.30\% [7].

\subsection{Fintech Activities in Indonesia}

Fintech has its activity in financial services in Indonesia that can be classified into five categories, namely:

a. Payments, transfers, clearing, and settlements

This activity has a close relationship with the digital payment process used by both banks and non-banks. Then there are electronic wallets, distributed ledger reporting, and electronic currencies. This model aims to increase financial inclusion and ensure the proper functioning of the payment system.

b. Deposits, borrowings, and capital additions

This activity is closely related to financial intermediation, its innovation in this field is the most common namely crowdfunding and Peer-to-Peer (P2P) Lending online lending platforms. There are also cryptocurrencies as well as Distributed Ledger Technology (DLT).

c. Risk Management

Risk management pays attention to the commitment and registration of guarantees and guarantees in credit operations. Fintech that participate in the insurance sector have a major influence on underwriting and risk pricing and settlement claims. And also affects the marketing and distribution of insurance.

d. Market Support

In this activity, access and contestability of information is an important issue. Where fintech can provide more effective processes such as e-aggregators, big data, digital ID verification, digital data storage and processing, or it can also be like the execution of orders through smart contracts.

e. Investment Management

This activity has a scope on e-trading platforms that can allow consumers to invest directly through digital electronic devices on every type of asset, smart contracts, and also on fintech innovations that can provide advice on financial services such as investment management and portfolio [10].

\subsection{Efforts of the Otoritas Jasa Keuangan}

Otoritas Jasa Keuangan efforts are divided into two, namely:

a. Issuance of Terms

1) Regulatory Sandbox

The issuance of POJK Number 77/POJK.01/2016 concerning Direct or Peer-to-Peer Lending (P2P) Lending services.

2) Further preparation from the OJK on crowdfunding, and digital banking.

b. Establishment of Fintech Innovation Hub at the OJK:

1) Coordination between Ministries and Institutions.

2) Development of fintech industry in accordance with the needs of the community.

3) Sandbox development for more potential fintech business models. 
4) The existence of means of communication between regulators and fintech in the industry such as fintech websites [11].

\subsection{Bank Perkreditan Rakyat}

Bank Perkreditan Rakyat (BPR) is a bank that carries out business activities conventionally or based on sharia principles, which in its activities does not provide services in payment traffic. BPR activities are much narrower when compared to the activities of commercial banks because BPR is prohibited from accepting giro deposits, foreign exchange activities, and insurance. Referring to the Law on banking Number 10 of 1998 (article 1), it is clearly said that commercial banks are banks that carry out business activities in conventional ways and or based on sharia principles that in their activities provide services in payment traffic. While Bank Perkreditan Rakyat (BPR) is a bank that carries out business activities conventionally or based on the principle of sharia which in its activities does not provide services in payment traffic.

\subsection{Types of BPR}

a. The type of BPR based on its ownership, BPR is divided into two includes:

1) Owned by BPR is the Government (generally Level II Local Government).

2) Privately Owned by BPR.

b. Types of BPR based on its management, the BPR is divided into two includes:

1) Conventional BPR (BPR).

2) BPR Syariah (BPRS).

c. While if viewed from the type, then BPR can be classified into three namely:

1) BPR Badan Kredit Desa (BKD). BKD is a financial institution operating in rural areas. However, in 1992, through the Banking Law, BKD was given status as BPR but with unique characteristics. Bank Desa and Lumbung Desa are examples of the type of BPR BKD.

2) BPR Is Not a Village Credit Agency. Examples are BPR ex LDKP (Lembaga Dana Kredit Pedesaan), Bank, BKPD (bank karya produksi desa), and Bank Pegawai. The third type is LDKP (Lembaga dana dan kredit pedesaan). This LDKP can be in the form of perusahaan daerah (PD), cooperatives, limited perseroan terbatas (PT), and other forms stipulated by government regulations.

\subsection{BPR Services}

a. Bank Perkreditan Rakyat Savings

In The Bank Perkreditan Rakyat savings account, customers are not charged an administration fee at the time of opening or closing the account. The initial deposit fee is fairly light. That is the range of Rp10,000-Rp100,000. The customer can also take the funds at any time, except for the type of term savings. Interest on BPR savings is in the range of $2 \%-6 \%$ per month. Unlike BPR Syariah, which only knows the revenue sharing system around $75: 25$ or if converted into interest then the value is about $5 \%$.

b. Bank Perkreditan Rakyat Deposits

While deposit products offered by BPR are relatively the same as those offered by commercial banks. For example, the interest on BPR deposits offered on average is at $6 \%$ every year. the deposit period provided starts from $1,3,6$, to 12 months. There is one 
interesting thing offered by some BPR related to its deposit products, namely the provision that customers can withdraw their funds at any time without any penalty.

c. Bank Perkreditan Rakyat

When it comes to the most iconic BPR products, of course, credit or loans. For credit products, arguably what BPR offers is quite diverse. All-access data banking services in large sizes and can be accessed app anywhere and anywhere. Depending on the innovation of each BPR. In general, the credit facilities offered by BPR are: 1) Business Credit, 2) Home Ownership Credit, 3) Small Business Credit, 4) Land Ownership Credit, 5) Multipurpose Credit. The terms of BPR credit are not much different from the society imposed by commercial banks. It is recognized that the presence of BPR in Indonesia can not be separated from the Usaha Mikro Kecil Menengah enterprises (UMKM). On the other hand, the needs of rural communities that have not been touched by commercial banks make BPR business opportunities wide open. The presence of BPR is certainly a fresh wind as well as a positive solution for rural communities to avoid the trap of loan sharks in gaining access to business credit. Because in principle, BPR serves the needs of capital with a relatively easy and fast crediting procedure. This is one of the advantages of BPR over commercial banks [12].

In the explanation of Fintech and BPR above, it can be seen that the main difference is in the operation of banking services. Operasional of Fintech in a modern way by implementing digital banking, while Operational of BPR in a traditionally way/non-digital that it is easily accessible to rural communities. On other Side, the Operational of Fintech and BPR services is equally bound to the Peraturan Otoritas Jasa Keuangan (POJK) that provide service limits in providing loans.

\subsection{Identification of Strength, Weakness, Opportunities and Threat of conditions BPR}

a. Strength

1) If seen from the total credits for the last three years, which continues to increase, Indonesians still need Bank Penkreditan Rakyat.

2) The BPR services are easy to be reached by people in rural areas.

3) The development of fintech can pose a threat termination of employment in Banking Industry.

b. Weakness

1) In the Regulation of Financial Service Authority number 12 /Pojk.03/2016, only BPRKU 3 can have electronic banking.

2) Compared to other banks, BPRKU 1 and BPRKU 2 have much less primary capital, so that they are not effective if digitalization is applied.

3) BPR services are not effective because they are still traditional.

4) The lack of digital knowledge on human resources of BPR in remote areas.

5) Not all people know the existence of BPR.

6) Public awareness began to grow in save and borrow financial needs through banking services.

7) The presence of Fintech will encourage banking to digitize and automate so that can maek service easier practical.

c. Opportunity

1) The Covid-19 pandemic has made people less having interaction, so electronic banking services are required. 
2) By digitalization, BPR coverage will be evenly distributed both in urban and rural areas.

3) The use of Fintech can lead to online crime, so that it can cause the customers to doubt making a transaction using Fintech.

4) The information technology infrastructure has not yet evenly throughout Indonesia causing inequality of access banking services.

5) The knowledge of people about fintech still relatively low.

6) Internet connection network is still lacking support for fintech access.

d. Threats

1) There is a BPR competitor currently, a fintech that facilitates the services with digital.

2) The development of Fintech in the last three years increases.

3) There is a Regulation of OJK No.77/POJK.01/2016 regarding Peer-to-Peer (P2P) Lending that makes it.

4) Fintech in Indonesia is already directly supervised by the Otoritas Jasa Keuangan (OJK) and regulated by Bank Indonesia (BI).

5) The Otoritas Jasa Keuangan and Bank Indonesia have ensured the security and confidentiality of the data belonging to providers and users of Fintech.

6) Fintech can help people who have not been able to serve by traditional finance industry.

\subsection{Formulated recommendations for the digital transformation of BPR with SWOT}

In strategy formulation, SWOT (Strength, Weakness, Opportunity, and Threat) analysis technique was carried out. Based on what has been done in target 1 , the first thing to do was making groups based on internal and external factors, where internal factors are strength and weakness. Meanwhile, the external factors are opportunities and threats. Then, the analysis was conducted to formulate strategies by seeing the relationship between strength and weakness owned by Kampung Genteng and the threat or opportunities from external factors. Thus, it gave several strategies with four crossings, SO Strategy (Strength-Opportunities), WO Strategy (Weakness-Opportunities), ST Strategy (Strength-Threat), and WT Strategy (WeaknessThreat).

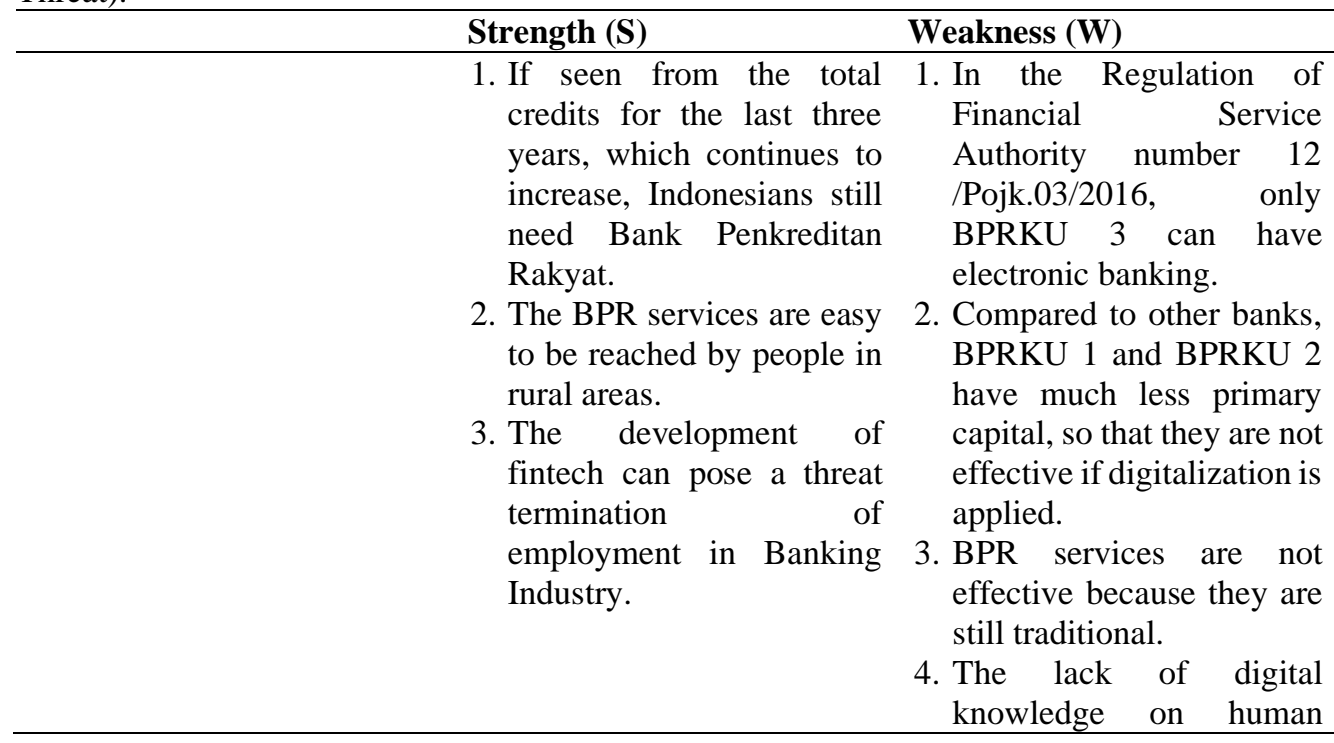


resources of BPR in remote areas.

5. Not all people know the existence of BPR.

6. Public awareness began to grow in save and borrow financial needs through banking services.

7. The presence of Fintech will encourage banking to digitize and automate so that can make service easier practical.

\section{Opportunity (O)}

1. The Covid-19 pandemic
has made people less
having interaction, so electronic banking services are required.

2. By digitalization, BPR coverage will be evenly distributed both in urban and rural areas.

3. The use of Fintech can lead to online crime, so that it can cause the customers to doubt making a transaction using Fintech.

4. The information technology infrastructure has not yet evenly throughout Indonesia causing inequality of access banking services.

5. The knowledge of people about fintech still relatively low.

6. Internet connection network is still lacking support for fintech access.

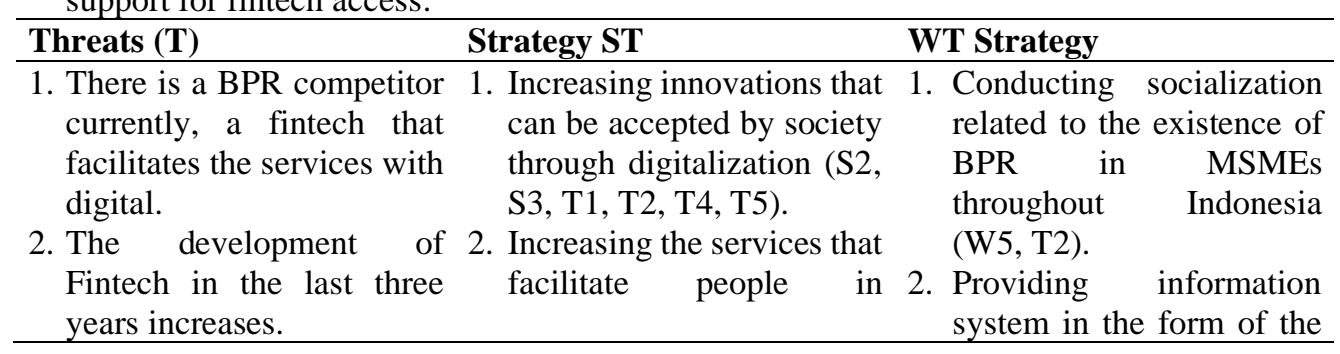

\section{SO Strategy \\ WO Strategy}

digital services include

digitalization of

information access,

digitalization of services

for costumers, and

digitalization of $\mathrm{BPR}$ business process (S1, S3, O1, O2, O4, O6, O7).

2. Principle-based provisions and regulations in the digital transformation of Bank Penkreditan Rakyat (BPR) are required in all areas $(\mathrm{S} 2, \mathrm{O} 2, \mathrm{O} 3, \mathrm{O} 5)$.
Seeing the needs of the electronic bank currently, especially during the covid-19 pandemic, the regulations of electronic banking restrictions on BPR should be updated by OJK (W1, W6, W7, O1, O3).

2. The BPR human resource training in information technology is to face the digital transformation throughout Indonesia (W3, O2, O4, O5).

3. The acceleration of the increase in capital for all types of BPR so that all types of BPR can have digital innovations (W2, O2). 


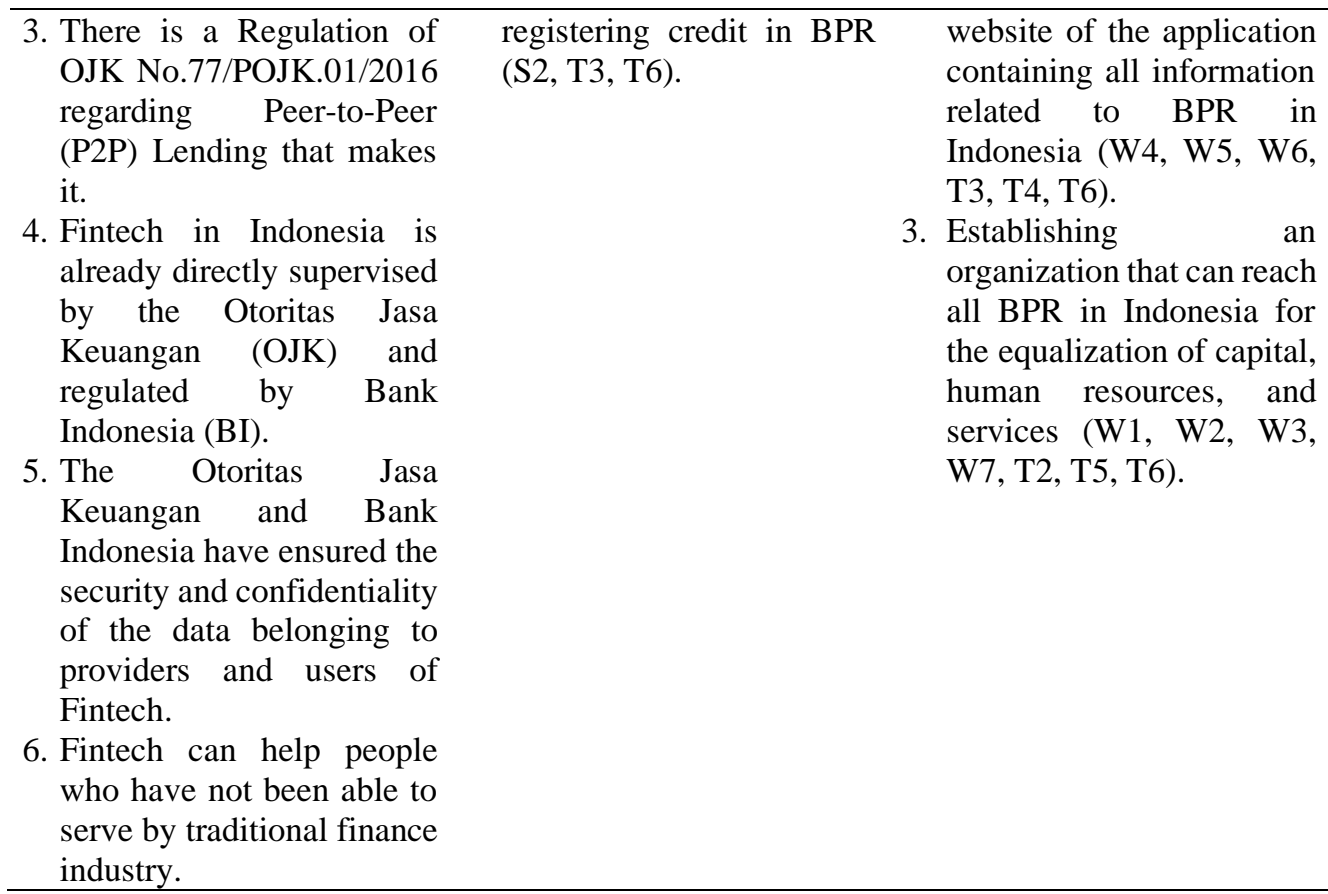

\section{Conclusion}

From the results of the study above, several strategies obtained were:

a. The improvement of BPR digital services include digitalization of information access, digitalization of services for costumers, and digitalization of BPR business process (S1, O1, $\mathrm{O} 2$ ).

b. Principle-based provisions and regulations in the digital transformation of Bank Penkreditan Rakyat (BPR) are required in all areas (S2, O2, O3).

c. Seeing the needs of the electronic bank currently, especially during the covid-19 pandemic, the regulations of electronic banking restrictions on BPR should be updated by OJK (W1, $\mathrm{O} 1, \mathrm{O} 3)$.

d. The BPR human resource training in information technology is to face the digital transformation throughout Indonesia (W3, O2).

e. The acceleration of the increase in capital for all types of BPR so that all types of BPR can have digital innovations (W2, O2).

f. Increasing innovations that can be accepted by society through digitalization (S2, T1, T2).

g. Increasing the services that facilitate people in registering credit in BPR (S2, T3)

$\mathrm{h}$. Conducting socialization related to the existence of BPR in MSMEs throughout Indonesia (W5, T2).

i. Providing information system in the form of the website of the application containing all information related to BPR in Indonesia (W4, W5, T3).

j. Establishing an organization that can reach all BPR in Indonesia for the equalization of capital, human resources, and services (W1, W2, W3, T2). 
From those strategies, the main strategy is to improve BPR services by digital, including digitalization of information access, digitalization of services for the customers, and digitalization of the BPR business process. Moreover, those strategies are the most related strategy to the current conditions, Covid-19 pandemic condition, by minimizing the direct contact from an individual. Therefore, the strategies obtained are expected to be a suggestion for BPR and other related stakeholders.

\section{References}

[1] Yuliana, "Corona Virus Diseases (Covid-19)," Wellness and Healthy Magazine, Lampung, pp. 187-182, 2020.

[2] World Health Organization, "Covid-19: Indonesia."

[3] I. W. Wiryawan, "Kebijakan Pemerintah Dalam Penanganan Pandemi Virus Corona Disease 2019 (Covid-19) Di Indonesia," Pros. Webinar Nas. Univ. Mahasaraswati Denpasar 2020, pp. 179$188,2020$.

[4] Our World in Data, "Covid-19: Google Mobility Trends, England and Wales," 2021.

[5] Otoritas Jasa Keuangan, "Indonesian Banking Statistics,” Jakarta, 2020.

[6] Regulation of the Otoritas Jasa Keuangan, "Business Activities and Network Areas of The Bank Perkreditan Rakyat's Core Capital Office," Jakarta, 2016.

[7] Otoritas Jasa Keuangan, "Development of Fintech Lending," 2021.

[8] F. Rangkuti, "SWOT Analysis: Business Case Dissecting Technique," Jakarta PT. Gramedia Pustaka Utama, 2008.

[9] M. Hadad, "Financial Technology (FinTech) in Indonesia," Jakarta, 2017.

[10] M. A. Nizar, "Financial technology (Fintech): it's concept and implementation in Indonesia," Munich Pers. RePEc Arch., no. 98486, 2017.

[11] B. Wibowo, "Analisis Regulasi Fintech dalam Membangun Perekonomian di Indonesia," $J$. Magister Tek. Elektro Univ. Mercu Buana, pp. 1-9, 2016.

[12] Andiaqsalwisani, “Apa itu Bank Perkreditan Rakyat?” Jakarta, 2020. 